UDC 811'33

DOI https://doi.org/10.32782/tps2663-4880/2021.18.32

\title{
NATURE AND CONSTITUTIVE FEATURES OF NARRATIVE AS UNIVERSAL DISCOURSE PATTERN
}

\author{
ПРИРОДА ТА ХАРАКТЕРИСТИКИ НАРАТИВУ \\ ЯК УНІФІКОВАНОГО ДИСКУРСИВНОГО ЗРАЗКА
}

\author{
Iegorova A.V., \\ orcid.org/0000-0003-4904-9123 \\ PhD in Philology, \\ Associate Professor at the Department of Foreign Philology and Translation \\ National Transport University
}

Within the scope of modern Cognitive and Discourse studies present article outlines various theoretical approaches to definition of narrative relying on specific macro- and microlevel narrative categories. Narrative is seen as a communicative event characterized by a specific discoursive pattern with universal content-semantic structure and formal organization, regular parameters (which correlate with the central category of eventfulness), and a set of pragmatic and cognitive functions (which are determined by narrator's pragmatic goals in compliance with a certain communicative situation, and roles of communicants in it).

First of all, the definition of narrative is provided. In its narrow sense it is understood as a fragment of discourse in the form of a sequence of related events characterized by a set of categories, rules and restrictions that distinguish it from other types of discourse. In its wider sense, narrative is defined as historically and culturally bound interpretation of certain aspects of the world from the point of view of a particular individual, which functions as a universal discourse pattern.

Further, a critique of event / eventfulness as the central narrative category is discussed along with the categories of resultativity, factivity, unpredictability and credibility adjacent to it.

Finally, having integrated several theories on narrative structuring, a comprehensive analysis of formal and semantic properties is presented. It encompasses theories developed by Barthes, Greimas, Levi-Strauss, Propp and Souriau (related largely to literature) along with more modern ones proposed by Hymes, Labov, Ochs and Capps, and van Dijk (by and large centred on conversational communication).

The author arrives at conclusion that narrative can be defined as a sample of discourse with universal semiotic, formal and semantic structure, characterized by regular features (all deriving from eventfulness category), and bearing specific cognitive and pragmatic functions. Even though it is clear that there may be variables in terms of communicative roles, modes, and media of communication, as well as socio-culturally bound genres, plots and topics, there are unique specifically narrative categories, structure, and functions that allow to classify narrative as a universal discoursive pattern.

Key words: narrative, narrator, event, actors, communicative act, communicative situation, pragmatic functions.

У роботі представлений аналіз теоретичних підходів до визначення наративу на основі його категоріальних ознак у рамках сучасної когнітивно-дискурсивної парадигми. Автор розглядає як макро-, так і мікрорівневі характеристики наративу. Наратив розглядається як комунікативна подія, що характеризується особливою дискурсивною організацією з універсальною змістовно-семантичною структурою, формальною організацією, регулярними параметрами (які корелюють із центральною категорією подієвості) та відповідним набором прагматичних і когнітивних функцій (із погляду наратора) відповідно до певної комунікативної ситуації й ролі комунікантів у ній.

Насамперед подається визначення наративу. В У сенсі він розуміється як фрагмент дискурсу у вигляді послідовності пов'язаних між собою подій, що характеризуються набором категорій, правил і обмежень, які відрізняють його від інших типів дискурсу. У більш широкому сенсі наратив визначається як історично й культурно зумовлена інтерпретація певних аспектів світу з погляду конкретної людини, що функціонує як універсальна дискурсивна модель.

Далі обговорюється центральна категорія наративу - подія / подієвість - разом із суміжними з нею категоріями результативності, фрактивності, непередбачуваності й правдоподібності.

Нарешті, об'єднавши кілька теорій про особливості структурування наративів, пропонується комплексний аналіз їх формально-семантичних властивостей. Він включає теорії, розроблені Бартом, Греймасом, Леві-Стросом, Проппом, Суріо (всі з яких так чи інакше пов'язані з літературними наративами), а також більш сучасні теорії, запропоновані Хаймсом, Лабовим, дослідницями Окс і Кеппс і ван Дейком (зосереджені на наративах в інтеракції).

Автор доходить висновку, що наратив можна визначити як зразок дискурсу з універсальною семіотичною, формальною та семантичною структурою, що характеризується регулярними параметрами (які пов'язані з категорією подієвості) та певними когнітивними й прагматичними функціями. Незважаючи на те, що можуть з'являтися певні змінні у комунікативних ролях, способах і засобах комунікації, соціально-зумовлених жанрах, сюжетах і темах, все ж існують унікальні наративні категорії, а також унікальна структура й фрунції наративу, які дозволяють класифікувати його як універсальний дискурсивний зразок комунікативної події.

Ключові слова: наратив, наратор, подія, актанти, комунікативна подія, комунікативна ситуація, прагматичні функції. 
Problem statement. Traditional narrative studies originate from the ideas of Aristotle in his "Poetics" and deal with novels, short stories, fairy-tales and other literary genres. Narrative theory started its rapid development at the beginning of the XX century, since then the shifts in general scientific paradigms and thinking have also influenced the scope of narrative research. Within the framework of Structuralist paradigm (R. Barthes, G. Genette, A.J. Greimas, C. Levi-Strauss, V. Propp, T. Todorov) researchers were looking for systemic relations underlying narratives, their formal and semantic structure, and their research was predominantly centered on literary texts. With the general shift to Pragmatics paradigm, research has centered on oral narratives arising in interaction, which gave way to shift attention to socio-cultural factors, context of storytelling, pragmatic goals, functions, and comprehension. From this perspective much research was performed by W. Labov, N. Norrick, T. Van Dijk, etc. With the advent of Cognitive-Discoursive paradigm, narrative research has centered on cognitive mechanisms and models of production, comprehension and reproduction of narratives, and academia has adopted the view that narrative represents universal form of cognitive structuring. Among the researchers working in this direction are J. Brockmeier, W. Chafe, K. Gergen, R. Harre, R. Franzosi, D. McAdams - to mention just a few. At the present stage of scientific research narrative is understood as a specific means not only of representation but also of construction and interpretation of reality. According to J. Brockmeier \& R. Harre, narratives, first of all, are specific forms of discourse which are inherent to our means of both knowledge acquisition, as well as of conceptualizing, structuring action and events, and ordering our experience. Moreover, they represent "models of the world and models of the self", and "it is through our stories that we construct ourselves as a part of our world" [1, p. 47, 53-54]. These two ideas are closely connected with cognitive science and discourse studies, which are currently in the limelight of academia's interest. Since much research is currently done from the perspective of narrative analysis in a variety of fields and multidisciplinary research, and narratives as discoursive events are studied in a variety of contexts: everyday, medical, forensic, political, etc., it seems to be necessary to summarize findings previously presented by researchers which represent universal constitutive features of narratives.

The purpose of the article is threefold: (1) to analyze theoretical approaches to narrative description; (2) to define major narrative categories, relevant for narrative production and comprehension; (3) to present theoretical overview of literature on formal and semantic structuring of narratives.

Definition and major categories. In contemporary linguistics narrative is understood as a specific type of discourse, characterized by a set of categories, rules and restrictions that distinguish it from other types of discourse. According to T. van Dijk, language users must be able to recognize narrative when they perceive it (by listening to it, or reading it), distinguish between narrative and non-narrative and produce their own narratives. Thus, from a cognitive point of view, this means that they are subconsciously aware of the categories, rules and restrictions that define narrative discourse, and are able to strategically use this knowledge in the processes of narrative production and comprehension [2, p. 6]. Moreover, as noted by J. Brockmeier \& R. Harre, telling stories is an "ingrained habit", as "we are habituated to a wide repertoire of storylines $\langle\ldots\rangle$ we grow into a cultural canon of narrative models" [1, p. 52].

Narrative can be defined as a historically and culturally bound interpretation of certain aspects of the world from the point of view of a particular individual, represented as a fragment of discourse in the form of a sequence of related events. Narrative operates with a set of regularities and rules that make it possible to integrate an individual case of storytelling into general, culturally established canon. As noted by Brokmeier \& Harre, "narratives operate as extremely changeable forms of mediation between the individual (and their specific reality) and the generalized canon of culture. Viewed this way, narratives are both models of the world and models of the self. It is through stories that we construct ourselves as part of our world" [1, p. 54].

The discoursive nature of narrative is manifested by its cognitive, meaningful and intentional structural conditionality on universal cultural scripts, national-specific subjects, pragmatic conditions and cognitive structural models of narratives; it is also determined by global contextualization and intertextuality of this complex communicative event. Thus, narrative is a part of reality modelled derivatively, unfolding in its own time and space according to the laws of semiospheres that have formed verbal and communicative consciousness of the narrator. However, narrative performs the function of world-modelling, because through its mediation the author/teller constructs their own event model and their own role in the development of these events, which is also modelling their identity.

The main constitutive feature of narrative is the event, which is manifested in the temporal change 
of situations or states. Moreover, as W. Schmid notes, "the changes of states and their circumstances do not need to be explicitly represented" [3, p. 3]. It is the notion of event which is central to all possible definitions of narrative and it is the succession of events or actions which differentiates a narrative discourse from non-narrative. As noted by van Dijk, narrative is an "action discourse" and, therefore, may contain action descriptions, i.e. sequences of propositions denoting actions or their component properties, causes/reasons, as well as consequences [4, p. 286; 5, p. 61].

The event is understood as a change in the initial situation, which can be: (a) an external situation in the world described (natural, actional or interactive events); (b) an internal situation of a character (mental events) [3, p. 2-3].

Schmid noted that the event should be understood as a gradable concept and offered five criteria to evaluate the degree of "eventfulness" [3, p. 9-12]: (1) Relevance of change: the possibility to define certain change in the event category depends on the overall world-view in certain culture, and internal axiology of the text, as well as axiology of the subject who is experiencing these changes; (2) Unpredictability: the event involves a paradox, a contradiction to "doxa", i.e. to a popular belief, expectation, normal course of events; (3) Persistence: an event depends on what impact it causes on thinking and actions of the subjects; (4) Irreversibility: eventfulness increases with decreasing likelihood of recurrence and/or cancellation of the new state; (5) Noniterativity: the change must be one-time, as repetition approximates narrative to descriptive discourse.

Schmid also identified two conditions for fullfledged eventfulness [3, p. 9]:

Factivity or reality of change, where desire, an idea, a dream, a hallucination of the subject of an action is not considered as relevant; in such cases, it is actually the act of desire, dreaming etc., which can be considered as an event.

Resultativity is the condition prescribing that the change has to take place within the narrative. If the change is just initiated it is an inhoative mode, if the subject just attempts to perform an action conative mode, if changes are in progress - durative mode.

Resultativity according to van Dijk [6; 7], can also be interpreted as a successful, unsuccessful, successful-by-chance and semi-successful action. The actions are defined as successful when the intentions of the agent of action coincide with its result. If the result is different from intention, the action is unsuccessful. And if the result coincides with inten- tion but not through the agent's actions, or the action succeeds but without required change in the world, the action is successful-by-chance [6, p. 296].

According to the semiotician J. Lotman, an event is any violation of normal, routine flow of life, it is "an occurrence, a meaningful departure from the norm" which "depends on one's concept of the norm", it is "a revolutionary element opposing accepted classification" [8, p. 234], and it "always involves the violation of some prohibition and is always a fact which takes place, though it need not have taken place" $[8$, p. 236]. This boundary can be topographic and pragmatic, of ethical, psychological or cognitive nature. Thus, an event is a certain departure from the legitimate, the standard in this world, a violation of one of the rules (laws, traditions), compliance with which is a guarantee of order and structure of the world [4]. Considering eventfulness of narrative, W. Labov noted that "if the event becomes common enough, it is no longer a violation of an expected rule of behaviour $<\ldots>$ it is not reportable" $[9$, p. 370]. The researcher defines a reportable event as least expected, non-trivial, having the greatest effect upon the needs and desires of the participants in the narrative [10].

So, if we compare the concept of eventfulness, developed by Lotman with the understanding of it by contemporary discourse-oriented linguistics, it is possible to conclude that the main feature of the narrative is unpredictability, grounded in subjective entropy. Narrative analysts understand eventfulness as realized through subjective entropy (in the normal sequence of events some unforeseen 'something' should occur, which makes the story exciting enough to meet the expectations of the audience) (4, p. 286-287; 2 , p. 14). In other words, a narrative has to be remarkable enough for the recipient to listen to it. A potential storyteller may expect that a story they are going to tell to the recipient, be it a joke, a gossip, or an anecdote from their own life, will result in certain reaction from the recipient - it might make them laugh, gloat or sympathise, or it may otherwise produce an effect of misunderstanding, making the recipient wonder "What was that?". The pragmatic effect of the story depends on how well the communicants know each other's background, how well they are tuned-in with each other in a particular communicative context, as well as on the rhetorical skills of the narrator, who may find certain means to make any events become interest-provoking.

Another important feature for narrative production (especially in narratives of personal experience) is that of credibility - the recipient must be sure that the events occurred exactly as the narrator says. 
According to W. Labov, credibility "rests upon listeners' belief that the most reportable event did in fact take place in real time" [10, p. 5]. Labov, however, also points to what he calls "a fundamental paradox of narrative", which is based on inverse relations between the notions of reportability and credibility: the more uncommon or unexpected the event is, the less credible it is $[10$, p. 6].

Eventfulness as the defining constitutive feature of narrative should be understood as a set of causally-bound events, which is a formal and substantive basis for structuring of this discoursive type. Therefore, it is logical that linguists and semioticians have tried to work out the structural invariant of narrative - its pattern.

Formal and semantic structure of narrative. One of the first attempts of narrative formal-structural analysis was put forward by Ronald Barthes. His theory rests on assumptions about the homogeneity of discourse in terms of formal organization and, therefore, the possibility of constructing a narrative text analogous to a clause model. Barthes proposed a three-level model of narrative discourse with the following semiotic levels: 'functions' (similar to ideas developed by V. Propp), 'actions' (in the sense used by Greimas when he defines characters as 'actants'), and 'narration' (which is roughly the level of discourse as understood by Todorov) [11, p. 243]. Barthes stressed that a special function "has a meaning only insofar as it takes its place in the general line of action of an actant; and this action in turn receives its ultimate meaning from the fact that it is being told, that is, entrusted to a discourse which possesses its own code" $[11$, p. 243]. In the theory developed by J.A. Greimas [12] this division corresponds to a superficial level of objective manifestation, anthropomorphic action, and level of conceptual operations.

The first level, which describes the characters and their actions in their semantic and subject specificity, is the level of functions, which has two classes: distributional and integrative. Distributional functions fall, in their turn, into cardinal and catalyses. Cardinal functions operate within logical and chronological links in the text, these are the moments of 'risk' in the narratives that create or solve situational uncertainty. They "form together finite sets combining very few terms; they are logically controlled, at once necessary and sufficient" [11, p. 250]. In other words, they make up a kind of framework, the skeleton of the story. Catalyses in narrative fill in space between cardinal functions and link them together, a catalysis "precipitates, delays, or quickens the pace of discourse, sums up, anticipates, and sometimes even confuses the reader $<\ldots>$ it constantly reactivates the semantic tension of discourse" and, therefore, the main function of these units is phatic, i.e. that of maintaining contact between the narrator and the recipient [11, p. 249]. Integrative functions help to reveal the emotional state of actants, their personality traits, character, identity and the atmosphere of events either implicitly (indices) or explicitly (informants). They identify people and circumstances in the events, thus creating illusion of reality, they "authenticate the reality of the referent to root fiction in the real world" [11, p. 249].

The second level, the level of actions, is based on the generalization of characters behavior as represented by actants and their functions. The notion of actant was first introduced by L. Tesnière to describe general syntactic functions, where he proposed a model consisting of three actants necessary for narrative action: agent, patient, and beneficiary [13]. J.A. Greimas, basing his work on the findings of Lévi-Strauss, Propp, Souriau and Tesnière, has developed actantial model in which an actant is understood as a class of concepts that combines different roles/protagonists in the same function. All in all he defined six functions which can be combined as binary oppositions on three axes [14]: (1) 'Subject' and 'object' are related on the axis of 'desire', where the subject is a function that combines all the attributes and actions of the protagonist who wants to get some desired object or reach desired goal. Accordingly, an object performs a function that indicates everything what the subject wants; (2) 'Helper' and 'opponent' are related within modality of 'power', where helper/donator is an actant who helps the subject, and the opponent generalizes the class that brings together all the characters and/or other forces that are opposing the subject, hindering the subject from getting what is desired; (3) 'Sender' and 'receiver' are related on the basis of modality of 'knowledge', where the sender is an actant who instigates the action, giving a task to the subject. And the recipient/receiver/beneficiary is an actor receiving some benefit from the actions of the subject or the helper.

A similar classification of actants in narrative, however, this time referred to as 'agents of actions' was proposed by van Dijk, where he defines the following [6, p. 298]: (1) 'antagonists' - two agents, who have contradictory purposes. One of the antagonists is the 'loser' and the other is the 'winner', basing on the outcome of intended result of certain action (failure or success); (2) 'helper' and 'collaborator' are understood as agents of auxiliary action, where helper takes part in a complex action, and collaborator takes part only in one or few actions in a complex 
action, both as intended by another agent; (3) 'interferer' is an agent who aims to prevent action(s) of one of the antagonists, the helper(s) or the collaborator(s).

There is a possibility that agents may bear syncratic features, simultaneously combining different functions in story construction, being, for example, a helper or a collaborator for one of the antagonists and at the same time an interferer to the other.

The third level is the level where the structures of the previous two levels are organized in speech, i.e. in actual narration process. The level of narration is "occupied by the signs of narration, which reintegrate functions and actions into the narrative communication, the latter being articulated by its giver and its recipient" [11, p. 264]. Moreover, any narrative is bound to a situation of narration, with a set of codified rules governing its production and comprehension. Depending on specific communicative situation (institutional or everyday talk with an array of further situational and contextual details, which may either limit the speaker or otherwise - give them free reign), the speaker may choose what to tell, and how to tell it, i.e. they can choose what can or should be omitted in their story, and how the story has to be delivered rhetorically.

Any contemporary research of narrative inevitably contains quotes and references to the works of Labov \& Waletzky [15] and Labov [9], who developed structural approach to the study of narrative. It includes invariant content and semantic parts of this discursive phenomenon, the combination of which provides eventfulness and major characteristics of narrative (subjective entropy, causality, reportability, credibility, etc.). Eventfulness as the defining constitutive feature of narrative should be understood as a set of causally-bound events, which is a formal and substantive basis for structuring of this discursive type.

According to Labov, the constituent components of narrative structure are: abstract, setting of orientation, complicating action, evaluation, resolution, and coda [9, p. 363]. T. van Dijk, in his cognitive theory of discourse, considers the components of the narrative as macrostructure components, an abstract semantic description of the global discourse content. In other words, every part of narrative must correspond to a set of propositions summarized in a macroproposition with invariant cognitive content [2, p. 12]. However, the components defined by van Dijk (setting, exposition, complication, evaluation, resolution and moral) correspond well with those allocated by Labov:

- abstract/setting summarizes the story, justifies the reason why it should be told and listened to;
- orientation/exposition indicates the temporal and spatial dimension of story and introduces its participants;

- complicating action/complication involves the actual event, a 'nuclei' of narrative communication, including the most reportable event and a sequence of other events, producing the causality sequence to enhance credibility of the story told;

- evaluation reveals the emotional attitude and judgment of the narrator to the situation and their role in it. Evaluation in narrative is understood as a 'secondary structure' and can occur in different parts of the narrative and be expressed in different ways, it generally penetrates the entire narrative [9, p. 369]. Evaluation is explicated in speech by emotionally expressive statements like: 'Can you imagine, I got scared stiff! I could never expect her to do that!', irony: '... and this blonde simply crashed into his car...', derogative vocabulary use, or abuse. Evaluation can be implicated, e.g. by paralinguistic means (gestures, facial expressions, etc.), on the phonetic level (interruption of the narrative by pauses, unusual intonation patterns, stammering), repetitions of the same or semantically close words (which will transmit the emotions of fear, shame, irritation, etc.), or unusual syntax;

- resolution exposes the outcome of the situation (either negative or positive) in the result of the agent's resisting the circumstances;

- coda/moral contains the pragmatic meaning of the story, signals the completion of the story.

The models proposed by Labov and van Dijk may be modified further and widened. For example Ochs \& Capps offer a narrative model as consisting of seven components [16, p. 173]:

1) setting - including time, location, physical, psychological, and socio-historic conditions, bodies of knowledge and other relevant background information;

2) unexpected event - unanticipated, usually problematic incident;

3) psychological/physiological response - change in person's thoughts, emotions, or somatic state, provoked by either (2), (5), (6), and/or other psychological/ physiological response (3);

4) object state change - alteration of the state of an entity in the physical world;

5) unplanned action - unintended behavior (non-goal-directed);

6) attempt - behavior initiated to attain a goal and resolve a problematic (2);

7) consequence - repercussion of (3), (4), (5) or (6).

It has also been noted that in situation of communication, these narrative components can be intro- 
duced by participants of the dialogue other than the primary teller $[17 ; 16]$. For example, the abstract may belong not to the narrator, but to the listener in form of initiating a question. This can happen, for example, in everyday communication exchanges: 'You're upset. Something happened?', or in a situation of forensic questioning: 'What did you do on Friday night, the thirteenth?'

Narrative structure, such as proposed by Labov, van Dijk, Ochs \& Capps, if maintaining all components can be generally described as an 'ideal' narrative, i.e. a narrative, which contains (either implicitly or explicitly) answers to all possible questions that may arise in relation to any of the characteristics of the event, any details in the recipient's mind. Any ideal narrative model, in its turn, can be reduced to what Labov calls a 'minimal narrative' [9, p. 360], which should contain at least two clauses bound by temporal juncture with irreversible temporal order.

Conclusions. Narrative can be defined as a sample of discourse with universal semiotic, formal and semantic structure. It is characterized by regular parameters, deriving from eventfulness category, and a set of characteristic pragmatic and cognitive functions. Despite obvious variety of communicative roles, modes, and media of communication, as well as socio-culturally bound genres, plots and topics, there are unique specifically narrative categories, structure, and functions of narrative that allow to classify it as a universal discoursive pattern, inherent to any speaker in the world, regardless of specific language they use.

\section{REFERENCES:}

1. Brockmeier J., Harre R. Narrative. Problems and promises of an alternative paradigm. Narrative and Identity: Studies in Autobiography, Self and Culture / ed. by J. Brockmeier, D. Carbaugh. Amsterdam : John Benjamins Publishing Co. 2001. P. 39-58.

2. Van Dijk T.A. Story Comprehension: An Introduction. Poetics. 1980. № 9. P. 1-21.

3. Schmid W. Narratology. An Introduction / Trans. from German A. Starritt. Berlin / New York : de Gruyter, 2010. P. 272.

4. Van Dijk T.A. Action, Action Description, Narrative. New Literary History. The Johns Hopkins University Press. 1975. Vol. 6. № 2. P. 273-294.

5. Van Dijk T. A. Pragmatic Connectives. Journal of Pragmatics. 1979. № 3. P. 447-456.

6. Van Dijk T.A. Philosophy of Action and Theory of Narrative. Poetics. 1976. № 5. P. 287-332.

7. Van Dijk T.A. Narrative Macrostructures. Cognitive and logical foundations. 1976. № 1. P. 547-568.

8. Lotman J. The Structure of the Artistic Text. / Trans. from Russian by R. Vroon. Michigan Slavic Contributions No. 7. University of Michigan, 1977. P. 314.

9. Labov W. Language in the Inner City: Studies in the Black English. Philadelphia: University of Pensilvania Press, 1972. 412 p.

10. Labov W. Uncovering the event structure of narrative. Georgetown University Round Table. Georgetown: Georgetown University Press. 2001. (Retrieved 15 August 2021from https://www.ling.upenn.edu/ wlabov/uesn.pdf)

11. Barthes R. An Introduction to the Structural Analysis of Narrative. Trans. Lionel Duisit. New Literary History: A Journal of Theory and Interpretation. 1975. Vol. 6. № 2. P. 237-272.

12. Greimas A.J. On Meaning: Selected Writings in Semiotic Theory / Trans. From French by P.J. Perron and F.H. Collins. Minneapolis : University of Minnesota Press, 1976. P. 237.

13. Tesnière L. Elements of structural syntax / Translated from French by T. Osborne and S. Kahane. Amsterdam \& Philadelphia, PA : John Benjamins, 2015. P. 780.

14. Greimas A. J. Structural Semantics: An Attempt at a Method. Lincoln : University of Nebraska Press, 1983. P. 325.

15. Labov W., Walezky J. Narrative analysis: oral versions of personal experience. Essays on the Verbal and Visual Arts: Proceedings of the 1996 Annual Spring Meeting of the American Ethnological Society / ed. by J. Helms. Seattle, WA : University of Washington Press, 1967. P. 12-44.

16. Ochs E., Capps L. Living Narrative: Creating Lives in Everyday Storytelling. Cambridge, MA : Harvard University Press, 2001. $352 \mathrm{p}$.

17. Hymes D. Ethnography, Linguistics, Narrative Inequality: Toward an Understanding of Voice. London : Taylor \& Francis, 1996. P. 258. 